Article

\title{
A Conceptual Framework Integrating "Building Back Better" and Post-Earthquake Needs for Recovery and Reconstruction
}

\author{
Manjiang Shi ${ }^{1,2}$, Qi Cao ${ }^{1, *}$, Baisong $\operatorname{Ran}^{1}$ and Lanyan Wei ${ }^{1}$ \\ 1 School of Civil Engineering and Architecture, Southwest University of Science and Technology, \\ Mianyang 621000, China; shimj111@163.com (M.S.); rrbaisong@163.com (B.R.); \\ my15182380078@163.com (L.W.) \\ 2 Institute of Geographical Sciences and Resources Research, Chinese Academy of Sciences, \\ Beijing 100864, China \\ * Correspondence: caoqi@swust.edu.cn
}

check for updates

Citation: Shi, M.; Cao, Q.; Ran, B.; Wei, L. A Conceptual Framework Integrating "Building Back Better" and Post-Earthquake Needs for Recovery and Reconstruction. Sustainability 2021, 13, 5608. https://doi.org/10.3390/su13105608

Academic Editor: John T. Cooper

Received: 4 March 2021

Accepted: 30 April 2021

Published: 18 May 2021

Publisher's Note: MDPI stays neutral with regard to jurisdictional claims in published maps and institutional affiliations.

Copyright: (c) 2021 by the authors. Licensee MDPI, Basel, Switzerland. This article is an open access article distributed under the terms and conditions of the Creative Commons Attribution (CC BY) license (https:// creativecommons.org/licenses/by/ $4.0 /)$.

\begin{abstract}
Global disasters due to earthquakes have become more frequent and intense. Consequently, post-disaster recovery and reconstruction has become the new normal in the social process. Through post-disaster reconstruction, risks can be effectively reduced, resilience can be improved, and longterm stability can be achieved. However, there is a gap between the impact of post-earthquake reconstruction and the needs of the people in the disaster area. Based on the international consensus of "building back better" (BBB) and a post-disaster needs assessment method, this paper proposes a new (N-BBB) conceptual model to empirically analyze recovery after the Changning Ms 6.0 earthquake in Sichuan Province, China. The reliability of the model was verified through factor analysis. The main observations were as follows. People's needs focus on short-term life and production recovery during post-earthquake recovery and reconstruction. Because of disparities in families, occupations, and communities, differences are observed in the reconstruction time sequence and communities. Through principal component analysis, we found that the N-BBB model constructed in this study could provide strong policy guidance in post-disaster recovery and reconstruction after the Changning Ms 6.0 earthquake, effectively coordinate the "top-down" and "bottom-up" models, and meet the diversified needs of such recovery and reconstruction.
\end{abstract}

Keywords: building back better; post-disaster needs; post-disaster recovery and reconstruction; environment and safety; community resilience

\section{Introduction}

Significant progress has been made in disaster prevention, mitigation, and postdisaster recovery and reconstruction in China after the 2008 Wenchuan earthquake, which has led to the formation of a "Chinese model" for recovery and reconstruction [1]. However, a gap exists between the reconstruction effect and the needs of the people in the area being reconstructed. Numerous studies and practices have indicated that simple or even rash post-disaster recovery and reconstruction has not only achieved the expected goals but also led to new social and natural risks [2]. In recent years, the occurrence of global natural disasters, including the intensity and frequency of earthquakes, has increased, resulting in the need for post-disaster recovery and reconstruction, which has become the "new normal" in social and economic development [3]. Post-disaster recovery and reconstruction is not only a comprehensive reflection of a country or region's economic level and organizational and management capabilities [4] but is also an approach that can reduce disaster vulnerability and effectively promote "leapfrog development" in disasterstricken areas [5]. Therefore, how an authority responds to different needs of people in a disaster area has become a common topic through post-disaster reconstruction to reduce social vulnerability and improve the ability of the community to aid disaster prevention 
and mitigation, especially for disaster reduction managers, post-disaster reconstruction experts, and urban and rural planners [6,7].

"Building back better" (BBB) was first used in Aceh, Indonesia in 2006 to advocate for post-tsunami recovery, and it aimed to reduce risk and improve living conditions [8]. Since then, $\mathrm{BBB}$ has been widely used in disaster risk reduction and recovery and post-disaster recovery plans, and it was also included in the 2015 Sendai Framework for Disaster Risk Reduction [9]. Although improving pre-disaster conditions is a common goal for recovery, BBB is still more of a political slogan [10] and has not effectively realized the needs and vision of survivors in the process of reconstruction [11-13]. In fact, understanding the characteristics of people's needs in a disaster area is crucial for recovery and reconstruction [14]. Studies have found that developing policies and plans based on the needs of the people and local cultures (from the perspective of survivors) not only improves people's satisfaction but is also imperative to maintaining social equity and promoting sustainable development $[15,16]$. Therefore, integrating the needs of survivors into the BBB conceptual framework and building a new framework based on these needs in order to guide policymaking, planning, and performance evaluation of post-disaster recovery and rehabilitation is a pressing and important task.

On the basis of the above research progress and existing problems of $\mathrm{BBB}$ and postdisaster needs assessment (PDNA), this study constructs an N-BBB conceptual framework based on the indicators of post-disaster needs and BBB. The Changning County Ms 6.0 earthquake of Sichuan Province, China is taken as an example to verify the applicability and policy enlightenment of N-BBB in post-disaster recovery and reconstruction through field investigation.

\section{Methodology}

2.1. Constructing the Theoretical Framework and Index System of N-BBB Based on a Literature Review

First, N-BBB must be "people-oriented, focusing on the needs of people in the disaster area" [17-19]. The process of identifying and assessing these needs can assist in ensuring social consensus and empowering residents. It can also assist in standardizing post-disaster recovery and reconstruction and make it a more scientific process [20]. N-BBB clarifies the key problem of "who will benefit from post-disaster recovery and reconstruction" [21].

Second, N-BBB includes disaster risk reduction (DRR) in the post-disaster recovery and reconstruction process, specifically from the early to mid-term stages [22]. The core concepts of traditional BBB have emphasized the role of nonphysical means, such as spatial planning, macropolicy, and disaster damage assessment, and have paid little attention to physical means, such as house structure, disaster prevention, and mitigation facilities [13]. In China, the vast rural areas do not have requisite public service facilities, such as disaster prevention and mitigation facilities, and medical and healthcare facilities [23]. Therefore, raising the standards of disaster prevention and mitigation through physical facilities should be a priority in reducing disaster vulnerability in these areas. Other measures such as spatial planning can help avoid disaster-prone areas through location selection, spatial zoning, and the establishment of ecological buffer zones [24].

Third, N-BBB advocates enhancing resilience through innovative management and technological progress. Resilience is a fairly new concept in the adaptation to global climate change and disaster risk management [25]. Different organizations define resilient communities differently; however, primarily it can be summarized as the ability to defend against risks, the ability to adapt to and make changes while in a state of shock, and the ability to recover and learn [26]. In terms of disaster risk, resilience can be considered the opposite of vulnerability [19]. This implies that all measures that intend to reduce vulnerability may increase resilience. In post-disaster recovery and reconstruction, family or individual resilience, social capital, and sustainable livelihoods of farmers in earthquakeprone areas are key indicators that affect family resilience [27]. Accessibility to community public infrastructure and community organizations is a key factor that affects community resilience [28]. Technological innovation also plays an important role. Dube [2] proposed 
that construction-related resilience could be developed through technological innovation, such as the incorporation of new materials, structures, and designs while building houses and infrastructure. The United Nations Office for Disaster Risk Reduction (UNISDR) states that the establishment of a mechanism for labor division and information sharing is key to ensuring the efficient implementation of BBB [29].

Based on the above ideas and principles, the N-BBB conceptual framework model consists of the following three core dimensions: post-disaster reconstruction needs, disaster risk reduction (DRR), and community resilience enhancement. The relationship between these dimensions constitutes a structure that is similar to a house (shown in Figure 1). Postdisaster reconstruction needs represent the roof of the house and guides the main content and the overall framework of post-disaster recovery and reconstruction, and it ensures the implementation of DRR and community resilience. DRR and community resilience are indispensable pillars that support the N-BBB. DRR focuses on the post-disaster recovery phase, while community resilience focuses on the long-term post-disaster reconstruction phase. Together, DRR and community resilience ensure the adaptability and sustainability of post-disaster recovery and reconstruction.

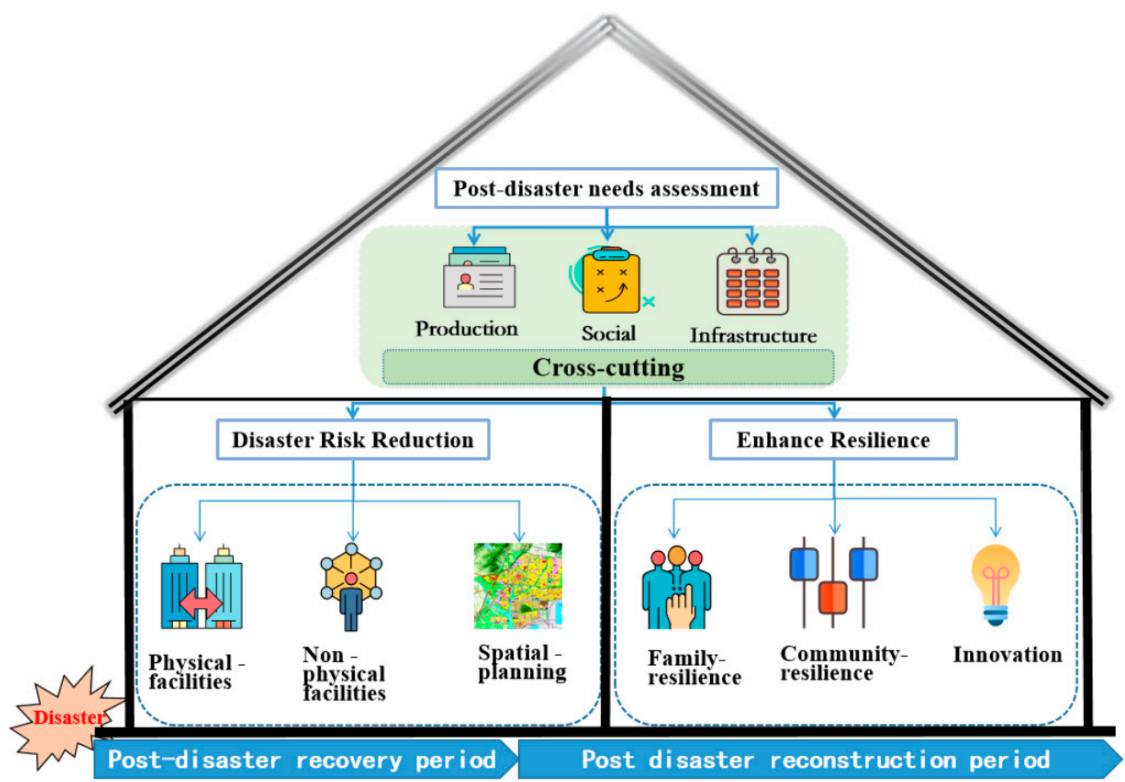

Figure 1. The theoretical N-BBB framework.

Based on the integration of BBB $[8,13,30]$ and the PDNA [17] index system, we selected the N-BBB indicators system, as shown in Table 1.

\subsection{Case Study Area}

On 17 June 2019, at 22:55, an Ms 6.0 earthquake struck Changning County, Yibin City, Sichuan Province (hereafter Changning Ms 6.0 earthquake). The earthquake caused 13 deaths and 299 injuries; more than 922 houses collapsed, and approximately 84,292 people were relocated. The crack degree of the earthquake-hit area was 7 degrees, while that of Shuanghe Town, Changning County, was 8 degrees. The earthquake-stricken area (with an intensity of over 7) spanned Changning County and Gong County (Figure 2). The epicenter was in Shuanghe Town, Changning County. Most of the disaster-stricken zones were old industrial and mining areas; these areas had high population density and many old houses with low earthquake resistance. Urban and rural residents' houses, public services, and municipal facilities were damaged, resulting in great loss. Regarding economic development, the disaster-stricken areas fell within impoverished counties and ethnic minority areas that had poor infrastructure, relatively slow social development, and a single industrial structure. 
Table 1. The index system of the N-BBB framework.

\begin{tabular}{|c|c|c|}
\hline N-BBB Dimension & Indicators & Interpretation \\
\hline \multirow{6}{*}{$\begin{array}{l}\text { Basic needs for } \\
\text { post-disaster recovery }\end{array}$} & $\begin{array}{l}\text { Standardized disaster damage and needs } \\
\text { assessment process }\end{array}$ & $\begin{array}{c}\text { Differences between national assessment and } \\
\text { local assessment }\end{array}$ \\
\hline & Production recovery and economic recovery & $\begin{array}{l}\text { Including recovery to baseline level before } \\
\text { disaster, reemployment, and so on }\end{array}$ \\
\hline & Social recovery & $\begin{array}{l}\text { Community security after the disaster, } \\
\text { psychological recovery in the disaster area, and } \\
\text { so on }\end{array}$ \\
\hline & Infrastructure & Road/water/electricity/gas/network, and so on \\
\hline & Division and cooperation & $\begin{array}{c}\text { The government, victims, external aid forces, } \\
\text { and other multi-body division of labor } \\
\text { and cooperation }\end{array}$ \\
\hline & Supervision and evaluation & $\begin{array}{l}\text { Empowerment of the people in the disaster area, } \\
\text { the third-party assessment of the reconstruction } \\
\text { process and effect, and so on }\end{array}$ \\
\hline \multirow{4}{*}{ Disaster risk reduction } & Early warning and forecast of disaster risk & $\begin{array}{l}\text { Disaster risk assessment, detection, and } \\
\text { prediction facilities }\end{array}$ \\
\hline & $\begin{array}{l}\text { Planning and design of disaster prevention } \\
\text { and mitigation }\end{array}$ & $\begin{array}{l}\text { Disaster prevention and mitigation and } \\
\text { preparedness planning under national policies } \\
\text { and laws/local knowledge }\end{array}$ \\
\hline & $\begin{array}{l}\text { Multi stakeholder participation mechanism } \\
\text { and guarantee system }\end{array}$ & Law and policy \\
\hline & Land and space security planning & Spatial planning reduces regional vulnerability \\
\hline \multirow{4}{*}{ Enhance resilience } & Technological innovation & New material and technologies \\
\hline & System and management innovation & $\begin{array}{l}\text { The system and management mode of } \\
\text { promoting community cohesion }\end{array}$ \\
\hline & Cultural heritage and local perception & $\begin{array}{l}\text { Local disaster prevention and } \\
\text { mitigation knowledge }\end{array}$ \\
\hline & Sustainable livelihoods & Diversity of livelihood modes \\
\hline
\end{tabular}

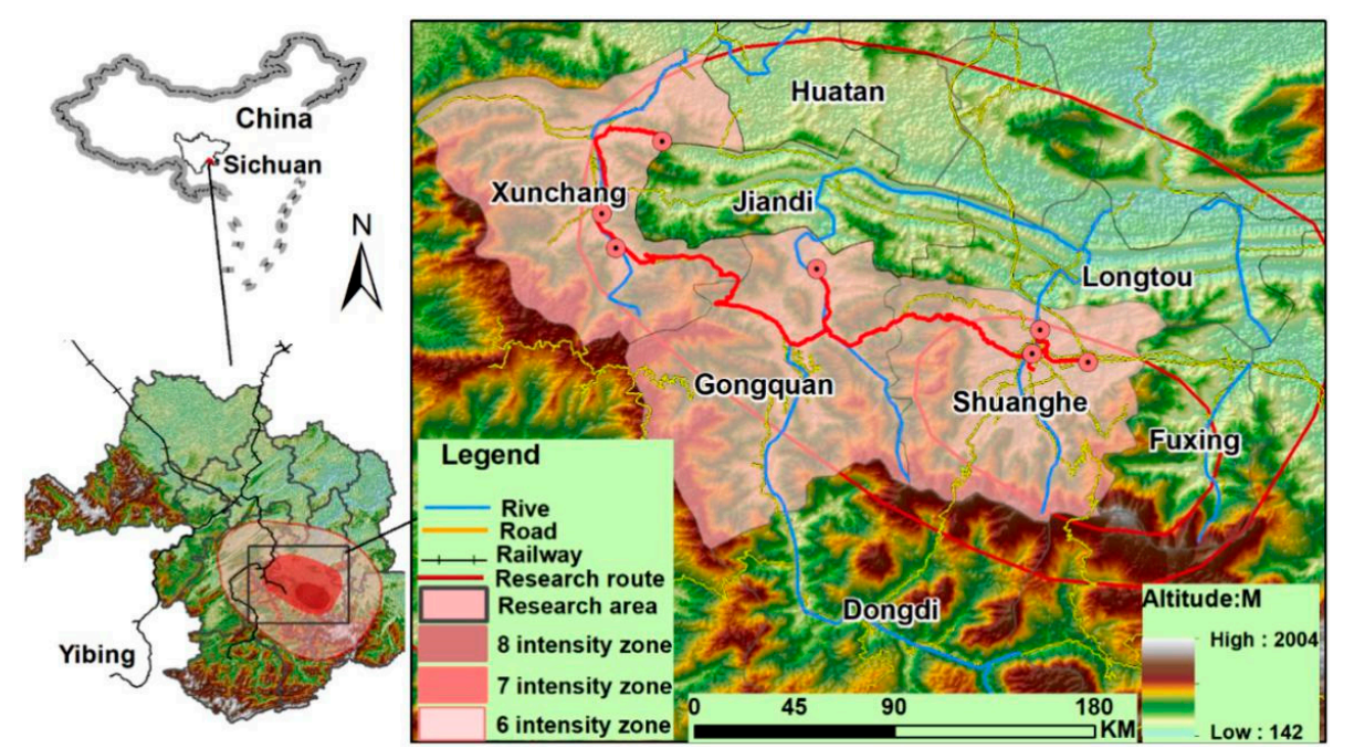

Figure 2. Location and seismic intensity map of the study area. 
Table 2 shows the data of this study's selected survey community, including the population, economy, and disaster damage.

Table 2. Data of investigated communities.

\begin{tabular}{|c|c|c|c|}
\hline Community/Village & $\begin{array}{c}\text { Demographic and } \\
\text { Economic Information }\end{array}$ & Post-Earthquake Damage & Community Type \\
\hline Shuanghe & $\begin{array}{c}\text { Population: } 7145 \\
\text { GDP: } 18,235 \text { RMB per year }\end{array}$ & $\begin{array}{c}\text { Affected people: } 4817 \\
\text { Died: 3; seriously injured: } 13 \\
\text { Buildings collapsed: } 869\end{array}$ & Market town \\
\hline Heye & $\begin{array}{c}\text { Population: } 768 \\
\text { GDP: } 10,235 \text { RMB per year }\end{array}$ & $\begin{array}{c}\text { Affected people: } 765 \\
\text { Died: 1; seriously injured: } 2 \\
\text { Buildings collapsed: } 144\end{array}$ & Village close to market town \\
\hline Putao & $\begin{array}{l}\text { Population: } 1842 \\
\text { GDP: } 11,000 \text { RMB per year }\end{array}$ & $\begin{array}{l}\text { Affected people: } 1400 \\
\text { Died: 4; seriously injured: } 13 \\
\text { Buildings collapsed: } 111\end{array}$ & Village close to market town \\
\hline Yuchi & $\begin{array}{l}\text { Population: } 1800 \\
\text { GDP: } 9000 \text { RMB per year }\end{array}$ & $\begin{array}{l}\text { Affected people: } 1623 \\
\text { Died: 1; seriously injured: } 5 \\
\text { Buildings collapsed: } 10\end{array}$ & Remote villages \\
\hline Fendong & $\begin{array}{l}\text { Population: } 1300 \\
\text { GDP: } 8000 \text { RMB per year }\end{array}$ & $\begin{array}{l}\text { Affected people: } 1300 \\
\text { Died: 0; seriously injured: } 10 \\
\text { Buildings collapsed: } 40\end{array}$ & Remote villages \\
\hline Xingtai & $\begin{array}{l}\text { Population: } 2130 \\
\text { GDP: } 16,000 \text { RMB per year }\end{array}$ & $\begin{array}{l}\text { Affected people: } 1300 \\
\text { Died: 0; seriously injured: } 10 \\
\text { Buildings collapsed: } 4\end{array}$ & Market town \\
\hline
\end{tabular}

\subsection{Field Investigation Method and Data Analysis}

This study used the technical process shown in Figure 3 to conduct field investigations and questionnaire collation. First, the N-BBB index and design questionnaire were selected. These were combined with the disaster situation of the case study area and the data in Table 2, and the N-BBB index system was constructed and the corresponding structured questionnaire designed. To ensure that the N-BBB index system corresponded closely with the actual situation of the disaster area and to facilitate quantitative analysis, a pre-test of the questionnaire was carried out through telephone calls and WeChat. Based on the feedback, the N-BBB index system and questionnaire were optimized.

\subsubsection{Field Investigation Method}

A structured questionnaire combined single-item selection and the scale method. The single-item selection included the basic situation of a family and the range of economic income. The scale method revolved around the N-BBB indicator system, and the respondent had to judge each need indicator in the questionnaire on the basis of their perception using a Likert scale [31] of the degree of needs (1-5, corresponding to not important, not clear, important, very important, and extremely important, respectively). The structured questionnaire's respondents were people from the disaster-stricken area, and those of the semi-structured interview were community managers and township cadres from the disaster area. Each structured questionnaire took about $30 \mathrm{~min}$, and the respondents were disaster victims. A total of 266 questionnaires were distributed, and 265 valid responses were collected. 


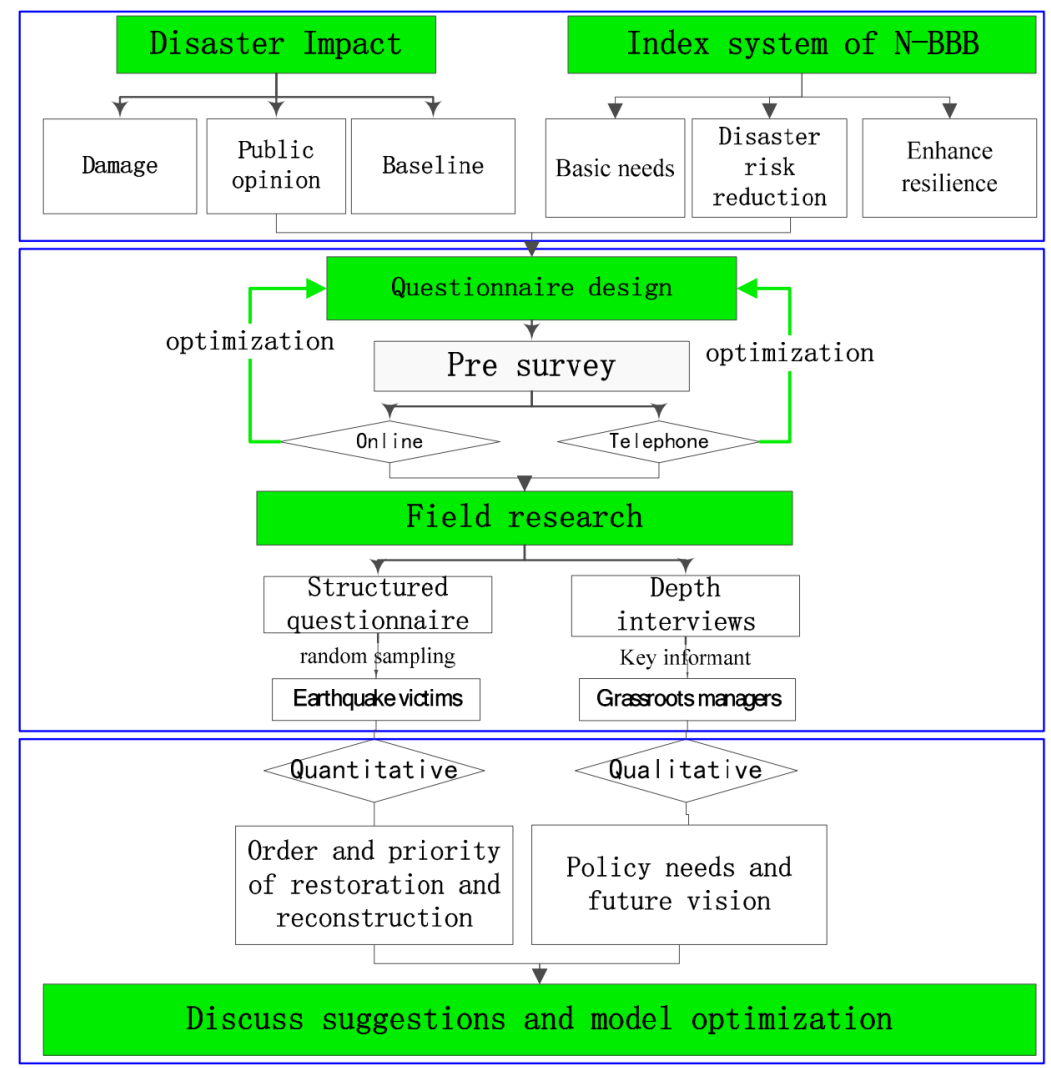

Figure 3. Technology roadmap of this study.

\subsubsection{Statistical and Analytical Methods}

The average value (means) of each index and corresponding standard deviation (SD) were calculated. The means represented the survivors' attention to a certain index, while the SD represented the cognitive differences among survivors. Then, the means and SD were divided into five grades using the natural breakpoint method in ArcGIS 10.7 software. (ESRI, Redlands, CA, USA)

To judge the reliability of the N-BBB in reality, we conducted factor analysis on the N-BBB indicators in SPSS 24 software. (IBM, Chicago, IL, USA) to compare whether the principal components extracted fully reflected the theoretical framework and corresponding N-BBB index system.

\section{Results and Analysis}

The N-BBB framework was combined with the characteristics of urban and rural communities and disaster damage in the affected areas and the improvement in indicators based on investigation and research to determine 35 demand indicators in the following 9 demand sectors: basic living assistance, industrial reconstruction and economic recovery, urban and rural housing, social security, urban and rural infrastructure, policy and planning, empowerment and participation, community reconstruction, and sustainable livelihoods. The statistical results of each index are shown in Table 3.

\subsection{Overall Response Characteristics}

Table 3 shows that the average value of the post-disaster needs index is 2.52 , which is categorized as "important" and reflects the urgency of the post-earthquake recovery and reconstruction process. From the perspective of the subsectors, the average values of the corresponding needs indicators for "basic living assistance", "social security", and "housing and safety" are higher than the overall average level (2.52). This reflects that sustainable assistance and safety guarantee, post disaster, have the highest priority among the demands of those affected, and this indirectly reflects the relatively fragile livelihood and disaster 
prevention and mitigation capacity of the area. This feature shows the difference between the needs of the people post disaster and during normal times.

Table 3. Priority and dispersion evaluation values of the N-BBB index in the Changning Ms 6.0.

\begin{tabular}{|c|c|c|c|c|}
\hline N-BBB Dimension & Sub-Dimension & Corresponding Needs Indicators & Mean & SD \\
\hline \multirow{16}{*}{$\begin{array}{l}\text { Basic needs for } \\
\text { post-disaster recovery }\end{array}$} & \multirow{5}{*}{ Basic living assistance } & Disaster damage assessment & 3.52 & 0.41 \\
\hline & & Insurance claims & 2.88 & 0.49 \\
\hline & & Emergency humanitarian assistance & 3.16 & 0.54 \\
\hline & & Government subsidy & 3.55 & 0.41 \\
\hline & & $\begin{array}{l}\text { Psychological comfort and assistance for the } \\
\text { people in disaster areas }\end{array}$ & 2.86 & 1.08 \\
\hline & \multirow{4}{*}{$\begin{array}{l}\text { Industrial and economic } \\
\text { reconstruction }\end{array}$} & $\begin{array}{l}\text { Damaged farmland and farmland and water } \\
\text { conservancy project restoration }\end{array}$ & 2.66 & 1.46 \\
\hline & & $\begin{array}{l}\text { Cultivate local and characteristic industries (e.g., } \\
\text { cold cake and salt mine processing) }\end{array}$ & 2.81 & 1.18 \\
\hline & & Attracting investment & 2.66 & 1.36 \\
\hline & & $\begin{array}{c}\text { Cultivating tourism in disaster areas (e.g., } \\
\text { bamboo tourism) }\end{array}$ & 2.81 & 1.18 \\
\hline & \multirow{3}{*}{ Urban and rural housing } & Housing reinforcement and repair & 3.53 & 0.86 \\
\hline & & $\begin{array}{l}\text { Repairing the original site of houses identified as } \\
\text { Grade C (i.e., a dangerous house; to be used after } \\
\text { reinforcement and maintenance) }\end{array}$ & 3.06 & 0.68 \\
\hline & & $\begin{array}{l}\text { Original site reconstruction of houses identified } \\
\text { as Grade D (i.e., critical; reinforcement and } \\
\text { maintenance needed and remains unable to } \\
\text { be used) }\end{array}$ & 3.16 & 0.56 \\
\hline & \multirow{4}{*}{ Social security } & Resumption of primary and secondary schools & 3.06 & 0.86 \\
\hline & & Hospital restoration and medical recovery & 3.39 & 0.68 \\
\hline & & $\begin{array}{l}\text { Strengthen the care for the old, weak, sick, } \\
\text { disabled, youth, and women }\end{array}$ & 3.44 & 0.72 \\
\hline & & $\begin{array}{l}\text { Strengthen the care for ethnic minorities and } \\
\text { foreign households }\end{array}$ & 1.95 & 1.38 \\
\hline \multirow{7}{*}{ Disaster risk reduction } & \multirow{5}{*}{$\begin{array}{l}\text { Urban and rural } \\
\text { infrastructure }\end{array}$} & Drinking water safety & 2.97 & 1.02 \\
\hline & & Power supply & 2.36 & 1.45 \\
\hline & & Rural ecological environment facilities & 2.84 & 1.22 \\
\hline & & Natural gas pipeline network & 2.06 & 1.46 \\
\hline & & Grade of village road & 2.86 & 1.26 \\
\hline & \multirow[b]{2}{*}{ Policy planning } & Original site reconstruction & 2.48 & 1.37 \\
\hline & & $\begin{array}{l}\text { Unified relocation to market town/centralized } \\
\text { resettlement area }\end{array}$ & 2.16 & 1.48 \\
\hline \multirow{5}{*}{ Enhance resilience } & \multirow{5}{*}{$\begin{array}{l}\text { Empowerment and } \\
\text { participation }\end{array}$} & $\begin{array}{l}\text { Enhance information disclosure and transparency } \\
\text { of recovery and reconstruction }\end{array}$ & 3.44 & 1.41 \\
\hline & & Provide suggestions for rehabilitation policy & 1.13 & 1.48 \\
\hline & & Participate in the planning process & 1.41 & 1.38 \\
\hline & & $\begin{array}{l}\text { Supervise the implementation process of } \\
\text { rehabilitation planning }\end{array}$ & 1.49 & 1.41 \\
\hline & & $\begin{array}{l}\text { Participate in the evaluation of the effect of } \\
\text { rehabilitation and reconstruction is in line with } \\
\text { public expectations }\end{array}$ & 1.45 & 1.15 \\
\hline
\end{tabular}


Table 3. Cont.

\begin{tabular}{|c|c|c|c|c|}
\hline N-BBB Dimension & Sub-Dimension & Corresponding Needs Indicators & Mean & SD \\
\hline & \multirow{5}{*}{ Community reconstruction } & $\begin{array}{l}\text { Regular (twice annual) publicity, training, and } \\
\text { drilling of disaster prevention and mitigation }\end{array}$ & 1.76 & 1.15 \\
\hline & & $\begin{array}{l}\text { Increase family/personal disaster prevention and } \\
\text { mitigation insurance }\end{array}$ & 1.60 & 1.08 \\
\hline & & Construction of rural emergency shelters & 2.28 & 1.43 \\
\hline & & Increase the number of rural disaster informants & 2.01 & 1.46 \\
\hline & & $\begin{array}{l}\text { Strengthen government capacity in disaster } \\
\text { forecasting/early warning }\end{array}$ & 2.26 & 0.98 \\
\hline & \multirow[b]{2}{*}{ Sustainable livelihoods } & Carry out reemployment skill training & 2.58 & 1.19 \\
\hline & & $\begin{array}{c}\text { Enhance the solidarity and cohesion of } \\
\text { neighbors/communities }\end{array}$ & 1.26 & 1.28 \\
\hline
\end{tabular}

Conversely, the average values of other indicators related to resilience, such as "provide suggestions to the policy of restoration and reconstruction" and "enhance unity and cohesion of neighbors or community empowerment and participation", do not garner as much of the respondents' attention. According to the average value for demand sector urgency, the order of demand urgency for each sector is as follows (from high to low): housing and security $>$ basic living assistance $>$ social security $>$ industrial reconstruction $>$ rural infrastructure $>$ policy planning $>$ community reconstruction $>$ empowerment and participation (Figure 4).

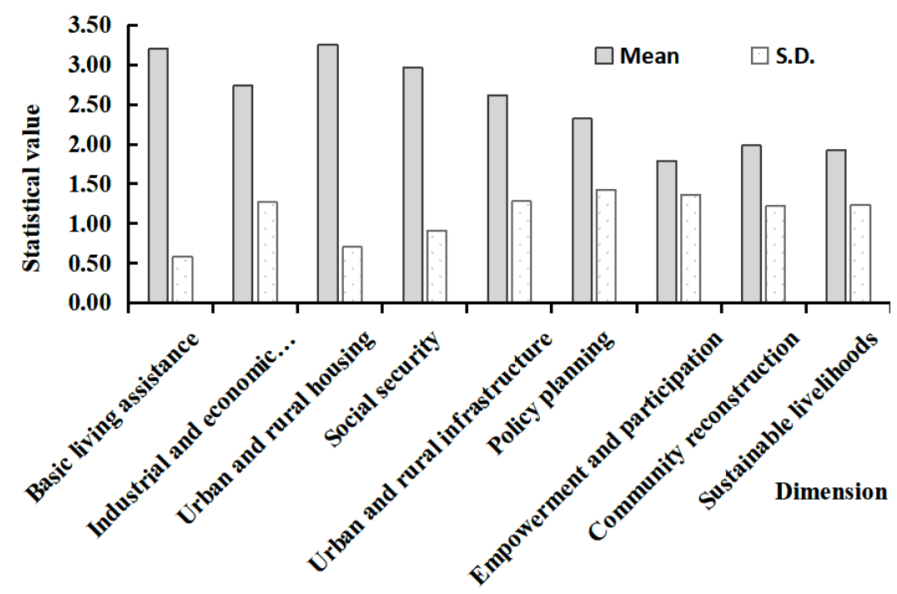

Figure 4. Distribution of the N-BBB index in rectangular coordinates.

Therefore, it is evident that respondents primarily focus on basic living security and disaster risk reduction management measures in the N-BBB model, and ignore the overall improvement of community resilience.

\subsection{Differences in Respondents' Attention}

As shown in Table 3, the SD of the index in the N-BBB model is 1.10, which is in the distribution range of "divergence". This reflects that the respondents have some divergence in the understanding of post-disaster demands. From the perspective of the demand indicators, "policy and planning", "empowerment and participation", "community reconstruction", and "rural infrastructure" are quite different. From the perspective of specific indicators, the public has the most divergent views for demand indicators such as "provide suggestions for recovery and reconstruction", "unified relocation to the centralized resettlement areas in towns/villages", "increasing the number of rural disaster information workers", and "increasing the number of natural gas pipeline networks", 
while the differences in indicators such as "basic living assistance", "housing maintenance", and "strengthening the care of vulnerable groups" are the least. The order of demand index dispersion is as follows: sustainable livelihoods $>$ policy planning $>$ industrial and economic recovery $>$ rural infrastructure $>$ empowerment and participation $>$ community reconstruction $>$ social security $>$ housing and security $>$ basic living assistance.

Additionally, the interviews indicated that the attention of the managers of basic-level townships in disaster-affected areas was primarily focused on post-disaster recovery and reconstruction policies and plans, but there were large differences among these managers in terms of their focus. First, the respondents considered the difference in government subsidies between family-level social capital and family labor post disaster. Therefore, they believed that a post-disaster subsidy standard based solely on the extent of housing damage was not completely unrealistic. Second, a huge difference was also observed in reconstruction methods, such as "reconstruction of the original site" or "uniform relocation to the centralized resettlement area of the township". Those who supported the reconstruction of original sites primarily based their opinion on the consideration of the distance and cost of agricultural cultivation (most of the victims' arable land was close to their homes), and those who supported relocation hoped that, through scientific site selection, they would be able to effectively avoid earthquake fault zones or geologically dangerous areas.

\subsection{Variations Among Different Communities}

Figure 5 shows that the spatial differences in the N-BBB, other than for Heye Village, indicate that the characteristics of the needs of different departments in other communities are similar to the above stated overall characteristics, but differences between different communities are also evident. The average demand value of each index in Shuanghe Community is higher than that of other communities, and is the lowest in Fendong Village. Therefore, in general, the more serious a disaster is, the higher the demand priority of the communities and market towns, compared to that of remote villages such as Shuanghe and Xingtai Communities.
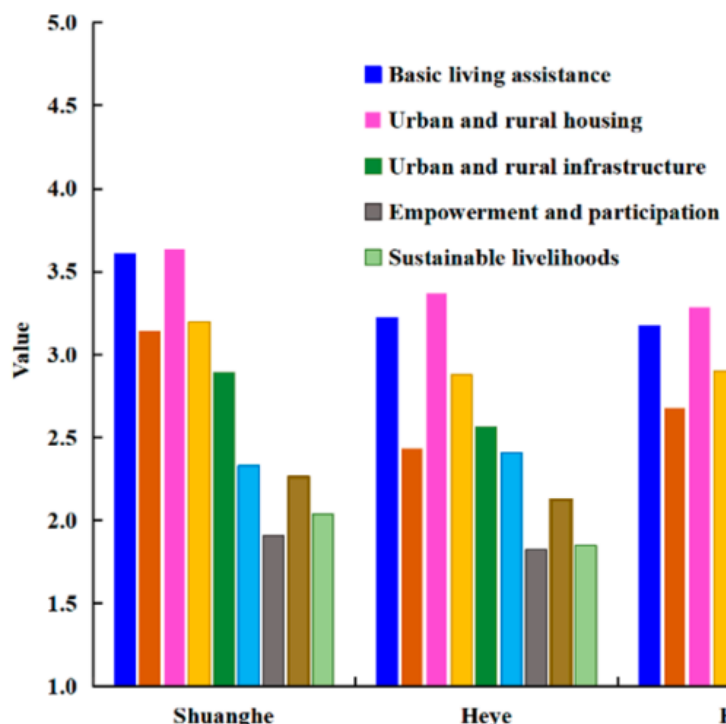

Community reconstruction

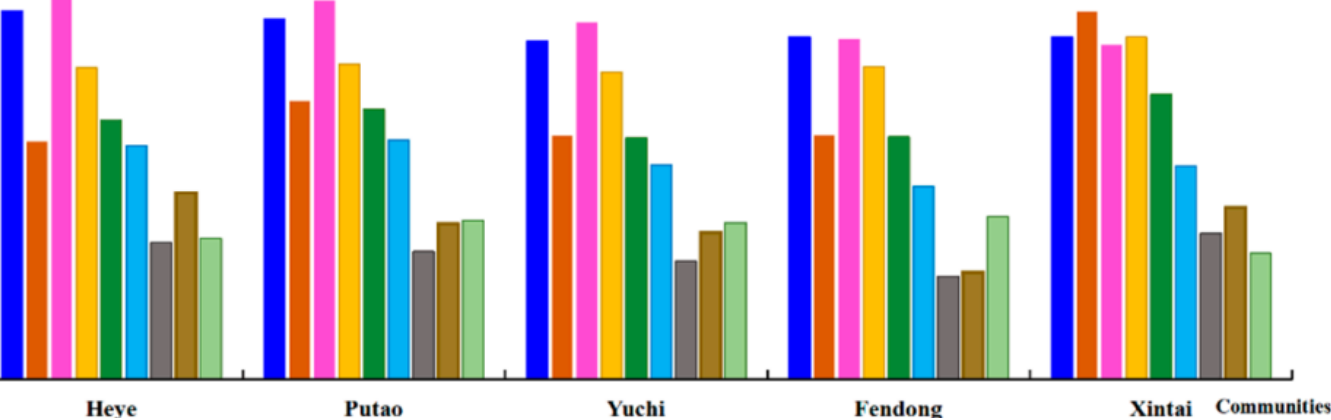

Figure 5. Distribution of the N-BBB index in rectangular coordinates.

In sum, it is evident that the respondents' needs for post-disaster recovery and reconstruction are focused on short-term life and production recovery, such as basic living assistance, housing safety, social security, and industrial and economic reconstruction, and they largely ignore long-term community reconstruction needs, such as community reconstruction, policy and planning, empowerment, and participation. This indicates that a reverse relationship exists between the dispersion of demand indicators and the order 
of priority, which implies that the understanding of the respondents is divided and that the differences are more based on the importance placed on the demand indicators. In addition to family, community, and degree of disaster damage, the role and responsibility of respondents in recovery and reconstruction will also affect their cognition of post-disaster needs. The survey found that ordinary people are primarily concerned with housing, livelihood, security, and other needs, while community managers pay more attention to social order and regional infrastructure while addressing the basic life-related needs of the affected people.

\subsection{Reliability of the N-BBB Model}

To test the reliability of the N-BBB in reality, we conducted factor analysis on 35 demand indicators in SPSS 24. (IBM, Chicago, IL, USA). First, the KMO value was 0.74, which is greater than the threshold value of 0.5 , indicating a correlation between variables, and the sig. was 0.00 , which is less than 0.05 .

Second, the cumulative interpretation of the first seven components in the total variance interpretation reached $74.37 \%$, including 28 indicators. A total of seven indicators were deleted, which indicated that there was strong collinearity between these indicators and the 28 indicators in the principal component; therefore, they were also deleted in the principal component. The gravel map is shown in Figure 6. Table 4 shows a component matrix of the seven principal components, which are clustered according to the order of reconstruction: post-disaster assistance, housing reconstruction, comprehensive reconstruction, participation and supervision, education and healthcare, and economic recovery. The seven dimensions and the corresponding index system N-BBB model (Figure 1) basically correspond to the indexes in Table 1 . Thus, the reliability of the N-BBB model in reality is verified.

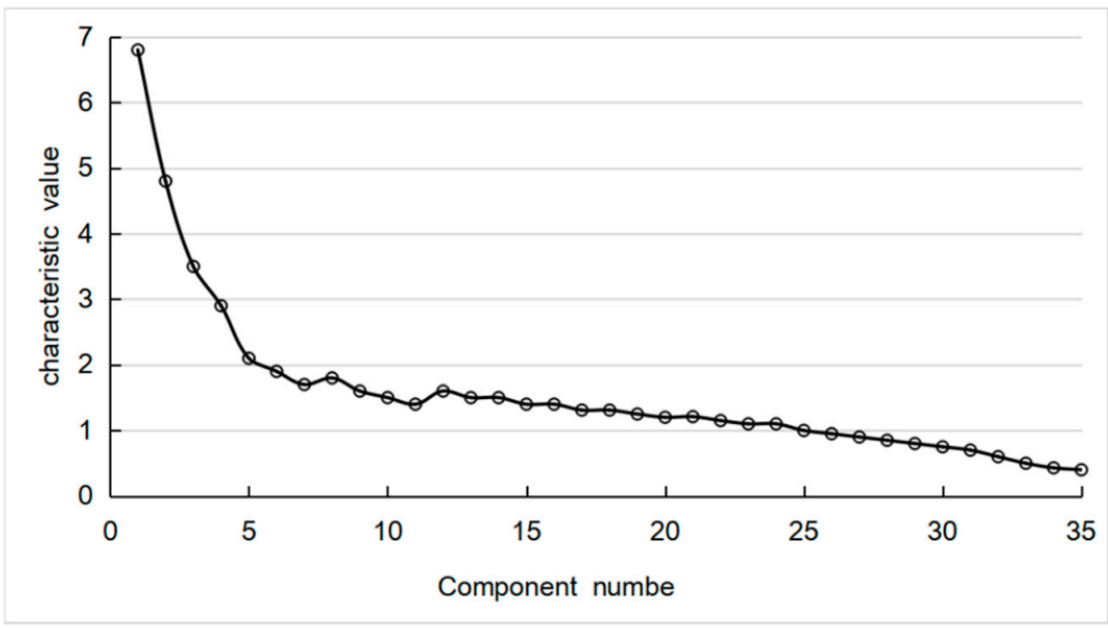

Figure 6. Screen test chart of factor analysis.

Table 4. Load value of each factor by principal component analysis.

\begin{tabular}{|c|c|c|c|c|c|c|c|c|}
\hline \multirow{2}{*}{ Clustering } & \multirow{2}{*}{ Indexes } & \multicolumn{7}{|c|}{ Principal Component } \\
\hline & & 1 & 2 & 3 & 4 & 5 & 6 & 7 \\
\hline \multirow{4}{*}{$\begin{array}{l}\text { Comprehensive } \\
\text { recovery and } \\
\text { reconstruction }\end{array}$} & $\begin{array}{l}\text { Strengthen the care for the old, weak, sick, } \\
\text { disabled, youth, and women }\end{array}$ & $0.69^{1}$ & 0.01 & 0.11 & 0.15 & 0.17 & -0.15 & -0.08 \\
\hline & $\begin{array}{l}\text { Carry out psychological comfort and } \\
\text { assistance for the people in disaster areas }\end{array}$ & 0.68 & -0.17 & -0.05 & 0.02 & 0.08 & -0.01 & -0.23 \\
\hline & $\begin{array}{l}\text { Cultivate tourism in disaster areas (e.g., } \\
\text { bamboo tourism) }\end{array}$ & 0.63 & -0.19 & -0.34 & 0.13 & -0.12 & 0.14 & 0.22 \\
\hline & Rural ecological environment facilities & 0.59 & -0.32 & -0.26 & -0.07 & -0.28 & 0.30 & 0.13 \\
\hline
\end{tabular}


Table 4. Cont.

\begin{tabular}{|c|c|c|c|c|c|c|c|c|}
\hline \multirow{2}{*}{ Clustering } & \multirow{2}{*}{ Indexes } & \multicolumn{7}{|c|}{ Principal Component } \\
\hline & & 1 & 2 & 3 & 4 & 5 & 6 & 7 \\
\hline & $\begin{array}{l}\text { Strengthening government capacity in } \\
\text { disaster forecasting/early warning }\end{array}$ & 0.58 & 0.04 & 0.28 & -0.46 & -0.18 & -0.23 & 0.29 \\
\hline & Carry out re-employment skill training & 0.57 & -0.08 & -0.17 & 0.05 & -0.36 & -0.05 & -0.18 \\
\hline & Construction of rural emergency shelters & 0.56 & 0.00 & -0.02 & -0.23 & 0.34 & -0.07 & -0.29 \\
\hline & $\begin{array}{l}\text { Regular (twice annually) publicity and } \\
\text { training and drilling of disaster prevention } \\
\text { and mitigation }\end{array}$ & 0.55 & -0.10 & -0.08 & 0.05 & -0.20 & 0.09 & 0.01 \\
\hline & $\begin{array}{l}\text { Increase family/personal disaster } \\
\text { prevention and mitigation insurance }\end{array}$ & 0.53 & -0.31 & -0.13 & -0.32 & 0.03 & 0.34 & -0.03 \\
\hline & $\begin{array}{l}\text { Increase the number of rural disaster } \\
\text { informants }\end{array}$ & 0.51 & -0.37 & 0.05 & -0.31 & 0.22 & 0.07 & -0.07 \\
\hline & $\begin{array}{c}\text { Enhance the solidarity and cohesion of } \\
\text { neighbors/communities }\end{array}$ & 0.50 & -0.42 & 0.21 & -0.03 & 0.31 & 0.17 & -0.13 \\
\hline \multirow{4}{*}{$\begin{array}{l}\text { Empowerment } \\
\text { and } \\
\text { participation }\end{array}$} & $\begin{array}{l}\text { Provide suggestions for } \\
\text { rehabilitation policy }\end{array}$ & 0.48 & 0.74 & -0.33 & 0.35 & -0.42 & -0.15 & -0.11 \\
\hline & Participate in the planning process & 0.50 & 0.69 & 0.03 & 0.10 & -0.11 & 0.06 & -0.06 \\
\hline & $\begin{array}{l}\text { Supervise the implementation process of } \\
\text { rehabilitation planning }\end{array}$ & 0.30 & 0.66 & 0.03 & 0.01 & -0.03 & 0.04 & -0.01 \\
\hline & $\begin{array}{l}\text { Participate in the evaluation of the effect of } \\
\text { rehabilitation and reconstruction is in line } \\
\text { with public expectations }\end{array}$ & 0.46 & 0.66 & 0.01 & 0.05 & -0.22 & 0.15 & 0.09 \\
\hline \multirow{4}{*}{$\begin{array}{l}\text { Urban and } \\
\text { rural housing }\end{array}$} & Housing reinforcement and repair & 0.57 & 0.11 & 0.71 & 0.01 & 0.13 & 0.18 & 0.01 \\
\hline & $\begin{array}{l}\text { Repair the original site of houses identified } \\
\text { as Grade C (i.e., a dangerous house; to be } \\
\text { used after reinforcement and maintenance) }\end{array}$ & 0.40 & 0.11 & 0.65 & -0.01 & 0.38 & -0.09 & 0.09 \\
\hline & $\begin{array}{l}\text { Original site reconstruction of houses } \\
\text { identified as Grade D (i.e., critical; } \\
\text { reinforcement and maintenance needed } \\
\text { and remains unable to be used) }\end{array}$ & 0.43 & -0.15 & 0.52 & 0.18 & 0.38 & -0.32 & 0.30 \\
\hline & $\begin{array}{l}\text { Unified relocation to market } \\
\text { town/centralized resettlement area }\end{array}$ & 0.50 & -0.27 & 0.44 & 0.16 & -0.02 & 0.06 & 0.45 \\
\hline \multirow{6}{*}{$\begin{array}{l}\text { Basic living } \\
\text { assistance }\end{array}$} & Emergency humanitarian assistance & 0.41 & -0.01 & 0.18 & 0.62 & 0.05 & -0.31 & 0.20 \\
\hline & government subsidy & 0.42 & -0.28 & 0.32 & 0.59 & 0.18 & -0.30 & -0.01 \\
\hline & Drinking water safety & 0.47 & -0.19 & 0.25 & 0.44 & 0.16 & 0.19 & 0.20 \\
\hline & Disaster damage assessment & 0.32 & -0.06 & 0.23 & 0.18 & 0.52 & 0.39 & -0.33 \\
\hline & Insurance claims & 0.41 & 0.11 & 0.35 & 0.35 & 0.49 & 0.38 & -0.43 \\
\hline & $\begin{array}{l}\text { Strengthen the care for ethnic minorities } \\
\text { and foreign households }\end{array}$ & 0.38 & 0.11 & 0.20 & 0.20 & 0.51 & -0.02 & 0.16 \\
\hline \multirow[t]{2}{*}{ Social security } & $\begin{array}{l}\text { Resumption of primary and } \\
\text { secondary schools }\end{array}$ & 0.36 & -0.15 & -0.49 & -0.49 & 0.16 & 0.56 & 0.06 \\
\hline & Hospital restoration and medical recovery & 0.34 & -0.27 & 0.02 & 0.02 & 0.23 & 0.49 & -0.11 \\
\hline \multirow{2}{*}{$\begin{array}{l}\text { Industrial and } \\
\text { economic } \\
\text { reconstruction }\end{array}$} & $\begin{array}{c}\text { Cultivate local industry and characteristic } \\
\text { industry (e.g., cold cake and salt } \\
\text { mine processing) }\end{array}$ & 0.33 & -0.01 & 0.24 & 0.24 & 0.11 & 0.19 & 0.55 \\
\hline & Attracting investment & 0.31 & -0.13 & 0.02 & 0.43 & 0.34 & -0.39 & 0.48 \\
\hline
\end{tabular}

${ }^{1}$ Bold shows the factor value greater than the load factor greater than 0.4 . 


\section{Discussion}

\subsection{Post-Disaster Reconstruction Based on the Needs of Survivors Cannot Address All BBB Goals}

This study found varying expectations of people in the disaster area in terms of post-disaster recovery and reconstruction projects; most focus only on short-term recovery and ignore long-term post-disaster reconstruction. Therefore, post-disaster reconstruction projects that are customized to the needs of these people cannot reduce vulnerability or enhance resilience in these areas.

Theoretically, post-disaster reconstruction and recovery provides an opportunity to resolve and correct social vulnerabilities [32]. When disaster-affected countries or communities attempt to reduce vulnerability in disaster-stricken areas and increase resilience at the family and community levels, reconstruction would result in more resilience [29]. This is the core concept that is emphasized by traditional BBB. However, this study found that, although post-disaster reconstruction provides opportunities to reduce the vulnerability of disasters in disaster-stricken areas, most post-disaster reconstruction projects have not achieved these goals [33,34]. The sociopolitical ecology perspective establishes that disasters often exacerbate or accelerate processes that are already occurring in communities, instead of changing them [35]. Hence, pre-existing inequalities may further manifest or become magnified because of disaster damages, thereby leading to unequal trajectories for housing recovery.

According to the reports on China Earthquake Network (http://news.ceic.ac.cn, accessed on 5 April 2021), several earthquakes have occurred in the study area in the last 10 years. This indicates that the earthquakes are of increasingly higher Ms, occurring at shorter intervals, and resulting in greater damage. For example, on 1 March 2011 and 25 April 2013, earthquakes with Ms 3.7 and Ms 4.8, respectively, struck the area. The earthquake in April led to the death of 1 person; 61 were injured, and 29,062 houses were damaged, which included 3565 seriously damaged houses and 27 that collapsed. From the example of the families in this survey, it was observed that most of the houses that had collapsed or were seriously damaged were old (wooden structures) or simple houses that had been used for many years, and some of them were also seriously damaged by previous earthquakes. Because of the lack of an extensive social network, the people living in these houses could not move into the homes of friends or relatives who were unaffected by the earthquake; they had to sleep on the street. The earthquake dealt a fatal blow to the families of vulnerable groups who could not avail government assistance or, because of their economic status, who were not eligible for bank loans. Conversely, some communities have richer resources, such as the processing industry and tourism (e.g., Shuanghe and Xintai in this study), and thereby have a higher ability to recover after the disaster. However, some communities must deal with a serious aging phenomenon and exist on a single livelihood, which aggravates the difficulty of post-disaster recovery and reconstruction (e.g., Fendong in this study). Additionally, under the policy of returning farmland to forest, most arable land in the disaster-stricken area has been converted into ecological land for bamboo forests; thus, the single livelihood source and fragile household economies have increased the impact of the disaster.

To avoid these problems, post-disaster reconstruction should combine short-term recovery with long-term reconstruction to ensure that the needs of survivors in the shortterm recovery process are addressed post disaster while reducing the vulnerability to the disaster and improving community resilience in long-term recovery and reconstruction. Therefore, only by combining the survivors' needs and the BBB principles can the goal of effective post-disaster reconstruction be achieved.

\subsection{The N-BBB in Improving the Mechanism of Post-Disaster Recovery and Reconstruction 4.2.1. Coordinating the Top-Down and Bottom-Up Models}

As part of the socialist system, which includes ensuring counterpart support and concentrated efforts to achieve goals, governments at all levels often adopt the top-down method and proceed from frameworks to content when formulating post-disaster recov- 
ery and reconstruction plans [36]. The main characteristic of this approach is that the reconstruction period is short, and the reconstruction effect is obvious. However, it largely ignores the diversified needs and vision of the people in the disaster area. According to Maslow's hierarchy of needs, there are many kinds of needs at the same time, place, and condition [37]. Among them, the most desired and unsatisfied need is the higher need, and this stimulates and drives human behavior.

The core concept advocated by the N-BBB, based on meeting basic living needs in post-disaster recovery and reconstruction, is to address the spontaneous higher needs, enhance the spirit of ownership and role in recovery and reconstruction, and gather the common needs and confidence of the people to ensure BBB. Therefore, in the process of post-disaster recovery and reconstruction, it is important that the post-disaster needs be assessed to establish a normalized and dynamic tracking mechanism, and that the characteristics of the people's needs are evaluated and coordinated with the government's top-down promotion and bottom-up reconstruction mode [38]. Further, the similarities and differences of the community's needs should be coordinated, and assessment results regarding the recovery and reconstruction should be reflected.

\subsubsection{Coordinating the Diversity of Post-Disaster Recovery and Reconstruction Needs}

Post-disaster recovery and reconstruction provides an opportunity to improve social equity and justice. The BBB advocates fairness and justice to reduce social vulnerability during post-disaster reconstruction. Disaster victims have different goals and visions for post-disaster recovery and reconstruction, which are influenced by many factors such as family, occupation, livelihood mode, and community. These are reflected in the different ways that are adopted by the community to achieve the BBB goals. This study found that, after the earthquake, some communities actively carried out self-help and postdisaster recovery and reconstruction under the leadership of the village committee, and community managers had detailed and ambitious plans regarding the same. Conversely, some villagers were passive, had low recognition of the work of the village committee, and had reservations about the impact of restoration and reconstruction. Therefore, over a long period of post-disaster recovery and reconstruction, it is difficult to assess the measures taken by different communities based on the BBB goals.

Additionally, during the same period, the reconstruction tasks and goals in different spaces (such as different types of communities) were also different. Therefore, "better" restoration and reconstruction should continue over time to meet the diversified goals, values, and regional cultural attributes of the different communities. The BBB should refine the target system at different periods of recovery and reconstruction based on the time sequence of recovery and reconstruction, and a recovery and reconstruction target mechanism should be established from the early stage of recovery to the mid-stage and then to the end of reconstruction that aims to "reduce the existing risks" and "improve the resilience of the community". From the perspective of space, the BBB should consider the diversified reconstruction goals of different communities, groups, and stakeholders to improve the overall satisfaction derived from rehabilitation and reconstruction.

\section{Conclusions and Recommendations}

This study attempts to integrate the needs of people in disaster-stricken areas with the $\mathrm{BBB}$ principles that have been advocated by the international community in order to build an N-BBB conceptual framework. Empirical analysis was conducted to verify its applicability and validity. The conclusions are as follows:

1. Overall, the N-BBB reflects the needs and vision of post-disaster recovery and reconstruction from different dimensions, and it includes required guidelines to achieve this vision and measures to reduce disaster risks and improve resilience. Empirical research has identified that focusing on the needs of the disaster area and using the guidelines advocated by the BBB can assist in overcoming the inequitable problem of post-disaster needs due to time constraints and can integrate the local needs for the 
BBB. The N-BBB can effectively address the policy and planning loopholes of disaster recovery and reconstruction to effectively achieve the BBB goals. Ideally, this model should be made a national guideline for post-disaster recovery and reconstruction.

2. The results of the Changning Ms 6.0 N-BBB included a total of 35 indicators in the following nine dimensions: basic living assistance, industry, housing, social security, rural infrastructure, policy planning, empowerment, community reconstruction, and sustainable livelihoods. It reflects the needs of the people after the earthquake in totality. However, post-disaster needs primarily focus on short-term recovery and relatively ignore long-term reconstruction planning. Thus, reliance only on PDNA to formulate policies and plans for disaster recovery and reconstruction has a certain one-sidedness. Therefore, for future restoration and reconstruction, measures should be taken to enhance resilience at the community and family level by adopting a more holistic approach.

The impact scope and disaster damage of the Changning Ms 6.0 earthquake were relatively less. In the interviews on disaster recovery and reconstruction needs, information was collected only from ordinary people and grassroots managers in the disaster area, which may affect the results of the PDNA. The N-BBB conceptual framework proposed herein takes the Changning Ms 6.0 earthquake disaster as an example, but lacks theoretical and empirical analyses of other types of disasters, such as floods and typhoons. In the future, an N-BBB conceptual model with a focus on other disasters should be constructed to assist in planning and implementing post-disaster recovery and reconstruction more effectively and fairly.

Author Contributions: Conceptualization, M.S.; methodology, Q.C.; software, M.S.; validation, Q.C.; formal analysis, M.S.; investigation, M.S., Q.C. and B.R.; resources, M.S.; data curation, M.S.; writingoriginal draft preparation, M.S.; writing-review and editing, Q.C. and L.W. All authors have read and agreed to the published version of the manuscript.

Funding: This research was funded by the National Natural Science Foundation of China, grant number 51908475 and 417001172.

Institutional Review Board Statement: Not applicable.

Informed Consent Statement: Not applicable.

Data Availability Statement: Not applicable.

Acknowledgments: We are very grateful to Hua Huang of Changning County Party School, Jun Zhang of Gongxian County Party School, and the five undergraduates (Baisong, Ran, Daiwen, AI. Rong, Ge. Qing, Tang, and Chengwen Wei) who participated in the field research.

Conflicts of Interest: The authors declare no conflict of interest.

\section{References}

1. $\mathrm{Xu}, \mathrm{J} . ; \mathrm{Lu}, \mathrm{Y}$. A comparative study on the national counterpart aid model for post-disaster recovery and reconstruction: 2008 Wenchuan earthquake as a case. Disaster Prev. Manag. 2013, 22, 75-93. [CrossRef]

2. Dube, E. The build-back-better concept as a disaster risk reduction strategy for positive reconstruction and sustainable development in Zimbabwe: A literature study. Int. J. Disaster Risk Reduct. 2020, 43, 101401. [CrossRef]

3. Paton, D.; Buergelt, P. Risk, transformation, and adaptation: Ideas for reframing approaches to disaster risk reduction. Int. J. Environ. Res. Pub. Health 2019, 16, 2594. [CrossRef] [PubMed]

4. National Strategy for Disaster Resilience. Building the Resilience of Our Nation to Disasters. 2011. Available online: https: // knowledge.aidr.org.au/media/2153/nationalstrategyfordisasterresilience.pdf (accessed on 10 February 2021).

5. Ge, Y.; Gu, Y.; Deng, W. Evaluating China's national post-disaster plans: The 2008 Wenchuan earthquake's recovery and reconstruction planning. Int. J. Disaster Risk Sci. 2010, 1, 17-27. [CrossRef]

6. Kennedy, J.; Ashmore, J.; Babister, E.; Kelman, I. The meaning of 'build back better': Evidence from post-tsunami Aceh and Sri Lanka. J. Conting. Crisis Manag. 2008, 16, 24-36. [CrossRef]

7. Mabon, L. Enhancing post-disaster resilience by "building back greener": Evaluating the contribution of nature-based solutions to recovery planning in Futaba County, Fukushima Prefecture, Japan. Landsc. Urban Plan. 2019, 187, 105-118. [CrossRef] 
8. Clinton, W.J. Lessons Learned from Tsunami Recovery: Key Propositions for Building Back Better (Office of the UN SecretaryGeneral's Special Envoy for Tsunami Recovery, 2006). GoSL. Post-Tsunami Recovery and Reconstruction Strategy. 2006. Available online: https:/ / pesquisa.bvsalud.org/portal/resource/pt/des-16694 (accessed on 21 February 2021).

9. UNISDR (United Nations Office for Disaster Risk Reduction). Sendai Framework for Disaster Risk Reduction 2015-2030; 2015, 32p. Available online: https://www.unisdr.org/we/inform/publications/43291 (accessed on 21 February 2021).

10. Fernandez, G.; Ahmed, I. "Build back better" approach to disaster recovery: Research trends since 2006. Prog. Disaster Sci. 2019, 1, 100003. [CrossRef]

11. Tian, C.; Fang, Y.; Yang, C.; Zhang, C. Spatial-temporal analysis of community resilience to multi-hazards in the Anning River basin, Southwest China. Int. J. Disaster Risk Reduct. 2019, 39, 101144. [CrossRef]

12. Li, Z.; Tan, X. Disaster-recovery social capital and community participation in earthquake-stricken Ya'an areas. Sustainability 2019, 11, 993. [CrossRef]

13. He, L. Identifying local needs for post-disaster recovery in Nepal. World Dev. 2019, 118, 52-62. [CrossRef]

14. Maly, E. "Rethinking "Build Back Better" in Housing Reconstruction: A Proposal for "People Centered Housing Recovery". In Proceedings of the IOP Conference Series: Earth and Environmental Science, Banda Aceh, Indonesia, 22-24 November 2016; Volume 56, p. 012025. [CrossRef]

15. Hinzpeter, K.; Sandholz, S. Squaring the circle? Integrating environment, infrastructure, and risk reduction in Post disaster needs assessments. Int. J. Disaster Risk Reduct. 2018, 32, 113-124. [CrossRef]

16. Evans, C.M.; Adams, R.M.; Peek, L. Incorporating mental health research into disaster risk reduction: An Online training module for the hazards and disaster workforce. Int. J. Environ. Res. Public Health 2021, 18, 1244. [CrossRef]

17. United Nations Development Programme (UNDP). Post-Disaster Needs Assessment (PDNA): Lessons from a Decade of Experience. 2018. Available online: https:/ / www.researchgate.net/publication/329631146_Post-Disaster_Needs_Assessment_ Lessons_from_a_Decade_of_Experience (accessed on 21 February 2021).

18. Ortega, J.; Vasconcelos, G.; Rodrigues, H.; Correia, M.; Lourenço, P.B. Traditional earthquake resistant techniques for vernacular architecture and local seismic cultures: A literature review. J. Cult. Herit. 2017, 27, 181-196. [CrossRef]

19. Davidson, C.H.; Johnson, C.; Lizarralde, G. Truths and myths about community participation in post-disaster housing projects. Habitat Int. 2007, 31, 100-115. [CrossRef]

20. United Nations Office for Disaster Risk Reduction (UNDRR). Words into Action Guidelines: Implementation Guide for Land Use and Urban Planning. 2020. Available online: https://www.undrr.org/publication/words-action-guidelines-implementationguide-local-disaster-risk-reduction-and (accessed on 21 February 2021).

21. Tatham, P.; Houghton, L. The wicked problem of humanitarian logistics and disaster relief aid. J. Humanit. Logist. Supply Chain Manag. 2011, 1, 15-31. [CrossRef]

22. Etinay, N.; Egbu, C.; Murray, V. Building urban resilience for disaster risk management and disaster risk reduction. Procedia Eng. 2018, 212, 575-582. [CrossRef]

23. Yong, Z.; Zhuang, L.; Liu, Y. Differences in the disaster-preparedness behaviors of the general public and professionals: Evidence from Sichuan Province, China. Int. J. Environ. Res. Pub. Health 2020, 17, 5254. [CrossRef]

24. Xiang, M.; Zhao, W.; Chen, J.A. Comparison of different reconstruction modes and adaptive evaluation systems for community recovery following the Wenchuan Earthquake. Sustainability 2018, 10, 4115. [CrossRef]

25. Aldunce, P.; Beilin, R.; Howden, M.; Handmer, J. Resilience for disaster risk management in a changing climate: Practitioners' frames and practices. Global Environ. Chang. 2015, 30, 1-11. [CrossRef]

26. Arbon, P.; Steenkamp, M.; Cornell, V. Measuring disaster resilience in communities and households. Int. J. Disaster Resil. Built Environ. 2016, 7, 201-215. [CrossRef]

27. Bilau, A.; Witt, E. An analysis of issues for the management of post-disaster housing reconstruction. Int. J. Strateg. Prop. Manag. 2016, 20, 265-276. [CrossRef]

28. Yang, H.; Dietz, T.; Yang, W.; Zhang, J.; Liu, J. Changes in human well-being and rural livelihoods under natural disasters. Ecol. Econ. 2018, 151, 184-194. [CrossRef]

29. United Nations Office for Disaster Risk Reduction (UNISDR). Build Back Better: In Recovery, Rehabilitation and Reconstruction (Consultative Version). 2017. Available online: https:/ /www.undrr.org/publication/words-action-guidelines-build-back-betterrecovery-rehabilitation-and-reconstruction (accessed on 21 February 2021).

30. Mannakkara, S.; Wilkinson, S. Selecting an institutional mechanism for building back better: Lessons from Victorian bushfires recovery. Int. J. Disaster Risk Reduct. 2016, 19, 273-279. [CrossRef]

31. Pescaroli, G.; Velazquez, O.; Alcántara Ayala, I.; Galasso, C.; Kostkova, P.; Alexander, D. A Likert scale-based model for benchmarking operational capacity, organizational resilience, and disaster risk reduction. Int. J. Disaster Risk Sci. 2020, 11, 404-409. [CrossRef]

32. Elaina, J.; Sutley; Sara, H. Post-disaster housing stages: A Markov chain approach to model sequences and duration based on social vulnerability. Risk Anal. 2020, 40, 2675-2695. [CrossRef]

33. Lewis, J. Housing construction in earthquake-prone places: Perspectives, priorities, and projections for development. Aust. J. Emerg. Manag. 2003, 18, 35-39.

34. Platt, S.; So, E. Speed or deliberation: A comparison of post-disaster recovery in Japan, Turkey, and Chile. Disasters 2017, 41, 696-727. [CrossRef] [PubMed] 
35. Khasalamwa, S. Is "build back better" a response to vulnerability? Analysis of the post-tsunami humanitarian interventions in Sri Lanka. Nor. J. Geogr. 2009, 63, 73-88. [CrossRef]

36. Yi, F.; Deng, D.; Zhang, Y. Collaboration of top-down and bottom-up approaches in the post-disaster housing reconstruction: Evaluating the cases in Yushu Qinghai-Tibet Plateau of China from resilience perspective. Land Use Policy 2020, $99,104932$. [CrossRef]

37. Williams, D.; Page, M. A multi-dimensional measure of Maslow's hierarchy of needs. J. Res. Personal. 1989, 23, 192-213. [CrossRef]

38. Rizzi, P.; Porębska, A. Towards a revised framework for participatory planning in the context of risk. Sustainability 2020, $12,5539$. [CrossRef] 